Jurnal Kesehatan Perintis (Perintis's Health Journal) 8 (1) 2021: 12-16

Contents list available at JKP website

STMES

PERINTIS

Jurnal Kesehatan Perintis (Perintis's Health Journal)

Journal homepage: https://jurnal.stikesperintis.ac.id/index.php/JKP

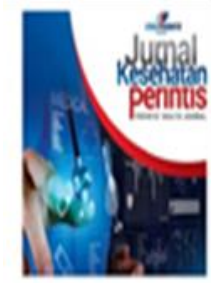

\title{
Hubungan Infeksi Soil Transmitted Helmith dengan Kadar Kolesterol \\ Darah Pada Anak dan Dewasa di Daerah Endemik Kecacingan Sumatera Barat
}

\author{
Nurhayati Nurhayati ${ }^{*}$, Hasmiwati Hasmiwati, Eka Novita \\ Bagian Parasitologi, Fakultas Kedokteran, Universitas Andalas, \\ Sumatera Barat, Indonesia
}

Article Information :

Submission: Jun 14, 2021; Revised: Jun 25, 2021; Accepted:Jun 29, 2021; Available online: Jun 30,2021

*Corresponding author : drnur165@gmail.com

\begin{abstract}
ABSTRAK
Soil transmitted Helminth (STH) merupakan penyebab tersering dari infeksi kronis pada usus manusia. Kemampuan cacing memodulasi respon imun host melalui Th2 yang memicu sitokin anti inflamatori diduga mempengaruhi kadar kolesterol darah pada individu yang terinfeksi STH, yang akan memiliki efek protektif terhadap penyakit metabolik. Oleh karena itu penelitian ini bertujuan melihat hubungan infeksi STH dengan kadar kolesterol darah, sebagai dasar helminthic therapy dan evaluasi terhadap program pengobatan massal. Infeksi STH diperiksa dengan pemeriksaan tinja metode langsung dengan iodine, sedangkan untuk mengukur jumlah telur per gram tinja dilakukan dengan metode Kato Katz. Kadar kolesterol total darah diperiksa dengan metode enzimatik CHOD-PAP. Semua subjek penelitian yang terinfeksi STH pada penelitian ini tergolong infeksi ringan. Kadar kolesterol individu yang terinfeksi STH didapatkan lebih rendah dibandingkan kadar kolesterol individu yang tidak terinfeksi STH, baik pada anak ataupun dewasa $(p<0,05)$, sehingga dapat disimpulkan bahwa terdapat hubungan yang bermakna antara infeksi STH dengan kadar kolesterol darah, sekalipun pada infeksi ringan.
\end{abstract}

Kata Kunci: kecacingan, STH, kolesterol darah

\begin{abstract}
Soil transmitted Helminth (STH) is the most common cause of chronic infection of the human intestine. The ability of worms to modulate the host's immune response through Th2 which triggers anti-inflammatory cytokines is thought to affect blood cholesterol levels in STH-infected individuals. Therefore, this study aims to look at the relationship of STH infection with total blood cholesterol levels. STH infection is examined by stool examination of the method directly with iodine, while to measure the number of eggs per gram of feces is carried out by the Kato Katz method. Total blood cholesterol levels are examined by enzymatic methods of CHODPAP and digital glucometer tools. All of the research subjects infected with STH in this study were classified as mild infections. The cholesterol levels of STH-infected individuals are lower than those of uninfected individuals $(p<0,05)$. So it can be concluded that there is a meaningful relationship between STH infection and total blood cholesterol levels, even in mild infections.
\end{abstract}

Keywords: worm, soil transmitted helminth, blood cholesterol 


\section{PENDAHULUAN}

Soil transmitted Helminth (STH) adalah cacing usus yang membutuhkan tanah sebagai media untuk perkembangan telurnya menjadi infektif. Cacing ini merupakan salah satu penyebab tersering dari infeksi kronis pada manusia. Beberapa jenis STH yang sering ditemukan adalah cacing cambuk (Trichuris trichiura), cacing gelang (Ascaris lumbricoides), dan cacing tambang (Necator americanus, Ancylostoma duodenale). Infeksi STH diklasifikasikan sebagai neglected diseases atau penyakit yang terabaikan, karena sering asimtomatis, dan jarang menimbulkan kematian (Pullan \& Brooker, 2012)

Infeksi STH paling sering dan menetap pada anak-anak dan orang yang tinggal di daerah endemik, karena terpapar sepanjang waktu selama hidupnya, mulai segera setelah lahir sampai usia dewasa. Prevalensi tertinggi terdapat pada anak usia sekolah dasar karena sering bermain di tanah dan karena perkembangan imunitas selulernya belum sempurna. STH dapat juga mengenai orang dewasa yang dipengaruhi oleh lingkungan sekitar dan pekerjaan, seperti orang yang bekerja di daerah kumuh dan terpapar langsung dengan tanah (Tekalign et al., 2019).

Infeksi cacing dapat menyebabkan gangguan gizi dan anemia. Gangguan gizi pada anak akan terlihat lebih jelas karena anak membutuhkan zat gizi yang lebih banyak untuk pertumbuhan (Suchdev et al., 2014). Dibalik dampak negatifnya tersebut, infeksi cacing ternyata memberikan efek protektif pada beberapa penyakit seperti alergi (Hamid et al., 2015; Sanya et al., 2017).

Infeksi cacing juga telah dilaporkan memberikan efek perlindungan terhadap beberapa penyakit seperti rheumatoid arthritis (Pineda et al., 2014) dan multipel sclerosis (Dixit et al., 2017).

Penelitian yang dilakukan terhadap hewan coba di Inggris menunjukkan, bahwa terdapat perbedaan plak aterosklerosis antara kelompok mencit yang diberikan antigen cacing Schistosoma hematobium, yaitu lebih sedikit, dibandingkan kelompok mencit yang tidak diberi antigen cacing di minggu ke 5 dan 6 setelah pemberian diet tinggi kolesterol. Pada kelompok mencit yang diberi antigen cacing $S$. hematobium terdapat kadar kolesterol darah yang lebih rendah secara bermakna dibanding kelompok mencit yang tidak diberi antigen cacing. Hal tersebut menunjukkan bahwa cacing dapat menurunkan kadar kolesterol darah sehingga perkembangan aterosklerosis dapat dihambat (Wolfs et al., 2014).

Pada penelitian di China, Chen menemukan bahwa prevalensi diabetes dan sindroma metabolik rendah pada lansia dengan riwayat infeksi cacing Schistosoma mansoni, ditandai rendahnya kadar kolesterol darah, glukosa darah, dan semua komponen sindroma metabolik lainnya, sehingga diasumsikan bahwa infeksi cacing dapat memberikan efek protektif terhadap sindroma metabolik, karena kadar kolesterol darah dan kadar glukosa darah adalah bagian dari komponen kedua penyakit tersebut. (Chen et al., 2013).

Adanya laporan bahwa efek protektif dari infeksi cacing berhubungan dengan kemampuan cacing memodulasi respon imun host (Grencis, 2015), memerlukan kajian lebih lanjut. Pada infeksi kronis, cacing memicu diferensiasi makrofag dari classically activated macrophages (CAMs) menjadi alternatively activated macrophag (AAMs) dan peningkatan jumlah sel $T$ regulator (Treg) yang ditandai dengan produksi sitokin anti inflamatori (Harris and Loke, 2017). Efek anti inflamatori ini merupakan antagonis dari TNF- $\alpha$ yang berperan dalam resistensi insulin. Oleh karena itu infeksi STH diasumsikan dapat meningkatkan sensitifitas insulin sehingga menurunkan kadar glukosa dan kolesterol di dalam darah, yang diperkirakan dapat menekan munculnya penyakit-penyakit yang berkaitan dengan kadar kolesterol dan kadar glukosa dalam darah.

Di Indonesia penelitian ini belum banyak dibahas. Penelitian yang dilakukan di daerah endemik kecacingan Flores Indonesia, mendapatkan kadar kolesterol total individu yag terinfeksi STH lebih rendah dibandingkan individu yang tidak terinfeksi STH (Wiria et al., 2013). Di Sumatera Barat juga telah dilakukan penelitian hubungan STH dengan kadar kolesterol darah di daerah endemik kecacingan, didapatkan kadar kolesterol individu yang terinfeksi STH lebih rendah bila dibandingkan individu yang tidak terinfeksi STH (Nurhayati, et. al., 2020), namun data yang dilaporkan dari Flores hanya usia dewasa 18-80 tahun, dan dari Sumatera Barat usia 11-65 tahun, sedangkan infeksi STH lebih sering menganai anak usia sekolah dasar dibandingkan dewasa, untuk itu dilakukan penelitian ini yang bertujuan melihat hubungan 
status infeksi STH dengan kadar kolesterol darah pada rentang umur responden yang lebih luas, melibatkan anak sekolah dasar dan dewasa.

\section{METODE PENELITIAN}

Penelitian analitik dengan pendekatan Case Control Study ini dilakukan pada anak usia sekolah dasar dan petani di Padang Pariaman dan Kota Padang. Total sampel 128 orang yang terbagi dua kelompok, yaitu 64 orang terinfeksi STH, dan 64 orang kontrol. Kontrol adalah individu yang tidak terifeksi dalam komunitas yang sama. Usia dan kelompok IMT hampir sama antara kedua kelompok. Pemeriksaan tinja untuk mengetahui STH dilakukan dengan metode Kato Katz. Kolesterol darah diperiksa dengan metode enzimatik CHOD-PAP. Kadar kolesterol diukur pada $520 \mathrm{~nm}$ spektrofotometer. Pemeriksaan dilakukan di Laboratorium Parasitologi dan Biomedik FK UNAND. Khusus untuk usia sekolah dasar kolesterol darah diukur dengan glukometer Nesco Multicheck Nw 07. Pada pengukuran normalitas data, didapatkan kadar kolesterol total tidak terdistribusi normal. Perbedaan ratarata kadar kolesterol antara individu yang terinfeksi STH dan kontrol dianalisis menggunakan uji statistik Mann Whitney $U$ dengan tingkat kemaknaan 95\% (alpha 0,05).

\section{HASIL DAN PEMBAHASAN}

Karakteristik dari responden dapat dilihat pada Tabel 1 sebagai berikut.

Tabel 1. Karakteristik responden

\begin{tabular}{lcc}
\hline Karakteristik & $\begin{array}{c}\text { Terinfeksi } \\
\text { STH }\end{array}$ & $\begin{array}{c}\text { Tidak } \\
\text { terinfeksi } \\
\text { STH } \\
\mathbf{n}=\mathbf{6 4}\end{array}$ \\
\hline Jenis kelamin & & \\
Laki-laki (f(\%) & $21(46,7)$ & $2(53,3)$ \\
Perempuan & $43(51,8)$ & $40(48,2)$ \\
Usia (tahun) & $6-65$ & $7-65$ \\
Anak & $39(61)$ & $39(61)$ \\
Dewasa (f (\%) & $25(39)$ & $25(39)$ \\
IMT (rata-rata) & $20,3 \pm 5$ & $20,2 \pm(4,9)$ \\
\hline
\end{tabular}

Pada Tabel 1 terlihat bahwa infeksi STH lebih banyak ditemukan pada individu dengan jenis kelamin perempuan $(51,8 \%)$ dan pada kelompok usia anak (61\%). Hasil penelitian ini berbeda dengan penelitian yang dilakukan di Jawa Timur (Charisma et al., 2020) dan Kalimantan Selatan (Annida et al., 2018) yang mendapatkan bahwa infeksi STH lebih banyak terjadi pada laki-laki dari pada perempuan. Belum ada data yang menyatakan bahwa jenis kelamin mempengaruhi kejadian infeksi STH. Kemungkinan tingginya jumlah perempuan yang terinfeksi STH pada penelitian ini dipengaruhi oleh kebiasaan, sanitasi, lingkungan, pendidikan, sosial, dan ekonomi (Sandy, et al.,, 2015; Arta Suryantari, 2019; Tekalign et al., 2019; Sastrawan et al., 2020).

Tabel 2. Distribusi frekuensi infeksi STH berdasarkan spesies dan derajat infeksi

$\begin{array}{cc}\text { Variabel } & \text { Frekuensi }(\%) \\ n=64\end{array}$

\begin{tabular}{lc}
\hline Jenis Cacing & \\
A. lumbricoides & $26(40,6)$ \\
T. trichiura & $18(28,1)$ \\
Cacing Tambang & $12(18,8)$ \\
Mix A. lumbricoides + & $7(10,9)$ \\
Trichuris trichiura & \\
Mix A. lumbricoides + & $1(1,6)$ \\
$\quad$ cacing tambang & \\
Intensitas infeksi & \\
Ringan & $64(100)$ \\
Sedang & $0(0)$ \\
Berat & $0(0)$
\end{tabular}

Jenis STH yang terbanyak ditemukan pada penelitian ini adalah Ascaris lumbricoides (40,6\%), diikuti Trichuris trichiura $(28,1 \%)$ dan cacing tambang $(18,8 \%)$, seperti yang terlihat pada Tabel 2 . Tingginya prevalensi infeksi oleh cacing Ascaris lumbricoides disebabkan karena dinding telurnya yang lebih tebal berfungsi melindungi isi telur, sehingga bertahan dalam waktu lama di tanah, sedangkan telur cacing parasit spesies lainnya berdinding lebih tipis kemungkinan lebih mudah rusak dengan lingkungan yang tidak sesuai. Selain itu juga jumlah telur yang dihasilkan oleh Ascaris lumbricoides lebih banyak jika dibandingkan dengan spesies cacing lainnya.

Pada penelitian ini sebagian besar infeksi cacing tambang didapat pada responden yang berumur dewasa. Padahal dewasa lebih tahu cara menjaga kebersihan dari pada anak-anak. Hal tersebut kemungkinan berhubungan dengan jenis pekerjaan mereka sebagai petani yang sehari-hari mereka kontak dengan tanah. Penularan terjadi tanpa mereka sadari karena cara infeksi cacing tambang bukan melalui 
tangan yang kotor, tetapi larva yang menembus kulit.

Semua subjek yang terinfeksi STH pada penelitian ini tergolong infeksi ringan, meskipun 10 orang yang berusia 11 tahun ke atas pada penelitian ini diketahui tidak memiliki MCK di rumahnya, mereka menggunakan sungai untuk jamban dan keperluan seharihari, sehingga kemungkinan besar selalu terpapar dengan cacing. Barangkali hal tersebut berhubungan dengan respon imun mereka yang telah berkembang baik. Respon Th2 meningkat sesuai dengan bertambahnya umur dan sebaliknya intensitas infeksi cacing akan makin menurun. (Grencis, 2015). Perbedaan kadar kolesterol pada individu yang terinfeksi STH dan tidak terinfeksi STH dapat dilihat pada tabel 3 .

Tabel 3. Perbedaan kadar kolesterol total pada individu yang terinfeksi dan tidak terinfeksi STH

\begin{tabular}{lccc}
\hline \multirow{2}{*}{$\begin{array}{c}\text { Kadar } \\
\text { kolesterol } \\
\text { (mg/dl) }\end{array}$} & \multicolumn{2}{c}{ Status infeksi } & $\begin{array}{c}\mathbf{P} \\
\text { value }\end{array}$ \\
\cline { 2 - 3 } & Terinfeksi & $\begin{array}{c}\text { Tidak } \\
\text { terinfeksi }\end{array}$ & \\
\hline Anak & $154,33 \pm$ & $180,97 \pm$ & 0,001 \\
& 27,77 & 34,542 & \\
Dewasa & $195,92 \pm$ & $230,67 \pm$ & 0,024 \\
& 39,911 & 30,471 & \\
Anak dan & $170,58 \pm$ & $195,77 \pm$ & 0,003 \\
Dewasa & 38,6 & 40,701 & \\
\hline
\end{tabular}

Pada penelitian ini kadar kolesterol pada individu yang terinfeksi STH pada anak, dewasa ataupun keseluruhan berturut turut terlihat lebih rendah secara bermakna dari pada individu yang tidak terinfeksi STH $(p=0,024 ; p=0,001, p=0,003 ;)$. Hasil ini hampir sama dengan hasil yang didapatkan oleh peneliti sebelumnya (Wiria et al., 2013).

Faktor perancu berupa pengaruh status gizi terhadap kadar kolesterol telah ditiadakan pada penelitian ini dengan memilih kontrol dengan yang usia dan kelompok indeks massa tubuhnya hampir sama dengan kasus, sehingga kemungkinan terbesar penyebab rendahnya kolesterol pada penelitian ini adalah adanya faktor respon imun.

Telah dilaporkan bahwa terlihat peningkatan bermakna dari akumulasi alternatively activated macrophages (AAMs) pada submukosa usus halus mencit yang diinfeksi dengan cacing Heligmosomoides polygirus $(\mathrm{Hp})$, yang melihatkan adanya peran suasana antiinflamatori pada infeksi cacing. (Morimoto et al., 2016).

Hal tersebut memperkuat penelitian sebelumnya yang melaporkan bahwa infeksi cacing kronis dan antigen derivat cacing menurunkan resistensi insulin sistemik (23\%), meningkatkan uptake glukosa perifer (25\%) dan meningkatkan sensitifitas insulin pada mencit obes melalui kerja sitokin antiinflamatori (Hussaarts et al., 2015).

Dapat dijelaskan bahwa infeksi cacing menginduksi produksi sel $T$ regulator dan eosinofil, menyebabkan polarisasi makrofag dalam jaringan lemak menjauh dari CAMc menuju AAMs, sebuah pergeseran terhadap AAMs disertai dengan produksi sitokin anti inflamatori, terutama IL-4, IL-5, IL-10, IL-13, dan TGF-B. Sitokin ini juga menghambat respon proinflamatori CAMs (Tracey, McDermott and McDonald, 2016). Jadi, melalui jalur Th2, cacing dapat meningkatkan sensitivitas insulin untuk mencegah perkembangan sindroma metabolik. Salah satu tanda bahwa cacing memiliki efek protektif terhadap sindroma metabolik adalah kolesterol darah yang lebih rendah pada individu yang terinfeksi STH. Dengan adanya efek protektif tersebut, maka program pengobatan massal tanpa didahului pemeriksaan intensitas infeksi perlu ditinjau ulang kembali.

\section{KESIMPULAN}

Dari hasil penelitian ini dapat disimpulkan barwa terdapat hubungan yang bermakna antara infeksi STH dengan penurunan kadar kolesterol darah, baik pada anak ataupun dewasa, meskipun pada derajat infeksi ringan.

\section{REFERENSI}

Annida, A. et al. (2018) 'Gambaran status gizi dan faktor risiko kecacingan pada anak cacingan di masyarakat Dayak Meratus, Kecamatan Loksado, Kabupaten Hulu Sungai Selatan', Journal of Health Epidemiology and Communicable Diseases, 4(2), pp. 54-64. doi: 10.22435/jhecds.v4i2.218.

Arta Suryantari, S. A. (2019) 'Prevalence, Intensity and Risk Factors of Soil Transmitted Helminths Infections Among Elementary School Students in Ngis Village, Karangasem District, Bali', Indonesian Journal of Tropical and 
Infectious Disease, 7(6), p. 137. doi: 10.20473/ijtid.v7i6.9952.

Charisma, A. M. et al. (2020) 'Prevalensi Telur Cacing Nematoda Usus Soil Transmited Helmint (Sth) Dengan Metode Konsentrasi Pada Siswa Mi Sunan Ampel 1 SidorogoTrosobo Kecamatan Taman Kabupaten Sidoarjo Provinsi Jawa Timur', Journal of Pharmaceutical Care Anwar Medika, 2(2), pp. 48-59.

Chen, Y. et al. (2013) 'Association of previous schistosome infection with diabetes and metabolic syndrome: A cross-sectional study in rural China', Journal of Clinical Endocrinology and Metabolism, 98(2), pp. 283-287. doi: 10.1210/jc.2012-2517.

Dixit, A. et al. (2017) 'Novel therapeutics for multiple sclerosis designed by parasitic worms', International Journal of Molecular Sciences, 18(10). doi: 10.3390/ijms 18102141.

Grencis, R.K., (2015). 'Immunity to helminth: Resistance, Regulation, and Susceptibility to gastrointestinal Nematodes'. Annual Review of Immunology. 33, pp.201-225.

Hamid, F. et al. (2015) 'Helminth-induced ige and protection against allergic disorders', Current Topics in Microbiology and Immunology, 388, pp. 91-108. doi: 10.1007/978-3-319-13725-4_5.

Harris, N. L. and Loke, P. (2017) 'Recent Advances in Type-2-Cell-Mediated Immunity: Insights from Helminth Infection', Immunity. Elsevier Inc., 47(6), pp. 1024-1036. doi: 10.1016/j.immuni.2017.11.015.

Hussaarts, L. et al. (2015) 'Chronic helminth infection and helminth-derived egg antigens promote adipose tissue M2 macrophages and improve insulin sensitivity in obese mice', FASEB Journal, 29(7), pp. 3027-3039. doi: 10.1096/fj.14266239.

Morimoto, M. et al. (2016) 'Regulation of type 2 diabetes by helminth-induced Th2 immune response', Journal of Veterinary Medical Science, 78(12), pp. 1855-1864. doi: 10.1292/jvms.16-0183.

Nurhayati, et al. (2020). 'Relationship Between Interleukin-10, Cholesterol and Blood Glucose Levels in Geohelminth Positive Adolescents and Adults'. Journal of Medical Sciences, 20 (1), pp. 18-23.

Pineda, M. A. et al. (2014) 'Lessons from helminth infections: ES-62 highlights new interventional approaches in rheumatoid arthritis', Clinical and Experimental Immunology, 177(1), pp. 13-23. doi: 10.1111/cei.12252.

Pullan, R. L. and Brooker, S. J. (2012) 'The global limits and population at risk of soiltransmitted helminth infections in 2010', Parasites and Vectors, 5(1), pp. 1-14. doi: 10.1186/1756-3305-5-81.

Sandy, S., Sumarni, S. and Soeyoko (2015) 'Analisis Model Faktor Resiko yang Mempengaruhi Infeksi Kecacingan yang Ditularkan Melalui Tanah pada Siswa Sekolah Dasar di Distrik Arso Kabupaten Keerom, Papua', Media Litbangkes, 25(1), pp. 1-14.

Sanya, R. E. et al. (2017) 'A life without worms', Transactions of the Royal Society of Tropical Medicine and Hygiene, 111(1), pp. 3-11. doi: 10.1093/trstmh/trx010.

Sastrawan, I. G. G. et al. (2020) 'Risk factors of soil transmitted helminth infection among primary school students', Health Science Journal of Indonesia, 11(2), pp. 126-132. doi: 10.22435/hsji.v11i2.2885.

Suchdev, P. S. et al. (2014) 'Soil-transmitted helminth infection and nutritional status among urban slum children in Kenya', American Journal of Tropical Medicine and Hygiene, 90(2), pp. 299-305. doi: 10.4269/ajtmh.13-0560.

Tekalign, E. et al. (2019) 'Prevalence and Intensity of Soil-Transmitted Helminth Infection among Rural Community of Southwest Ethiopia: A Community-Based Study', BioMed Research International, 2019. doi: 10.1155/2019/3687873.

Tracey, E. F., McDermott, R. A. and McDonald, M. I. (2016) 'Do worms protect against the metabolic syndrome? A systematic review and meta-analysis', Diabetes Research and Clinical Practice. Elsevier Ireland Ltd, 120, pp. 209-220. doi: 10.1016/j.diabres.2016.08.014.

Wiria, A. E. et al. (2013) 'Relationship between Carotid Intima Media Thickness and Helminth Infections on Flores Island, Indonesia', PLOS ONE, 8(1). doi: 10.1371/journal.pone.0054855.

Wolfs, I. M. J. et al. (2014) 'Reprogramming macrophages to an anti-inflammatory phenotype by helminth antigens reduces murine atherosclerosis', FASEB Journal, 28(1), pp. 288-299. doi: 10.1096/fj.13235911. 